\title{
The Global Boundary Stratotype Section and Point (GSSP) of the Messinian Stage (uppermost Miocene)
}

\begin{abstract}
1 Department of Geology, Faculty of Earth Sciences, Utrecht University, The Netherlands (fhilgen@ geo.uu.nl).
2 Dipartimento di Scienze della Terra, Universita degli Studi di Parma, Parma, Italy.

3 Paleomagnetic Laboratory "Fort Hoofddijk", Budapestlaan 17, 3584 CD Utrecht, The Netherlands.
\end{abstract}

\begin{abstract}
The GSSP of the Messinian Stage, which per definition marks the base of the Messinian and, hence, the boundary between the Tortonian and Messinian Stages of the Upper Miocene Subseries, has recently been defined and ratified by the IUGS. The boundary stratotype section is Oued Akrech (Morocco) where the Messinian GSSP is now formally designated at the base of the reddish layer of sedimentary cycle no.15. This point coincides closely with the first regular occurrence (FRO) of the planktonic foraminiferal Globorotalia miotumida group and the first occurrence (FO) of the calcareous nannofossil Amaurolithus delicatus, and falls within the interval of reversed polarity that corresponds to C3Br.1r. The base of the reddish layer and, thus, the Messinian GSSP has been assigned an astronomical age of $7.251 \mathrm{Ma}$.
\end{abstract}

\section{Introduction}

The aim of this paper is to announce the ratification of the Global Boundary Stratotype-section and Point (GSSP) of the Messinian Stage (uppermost Miocene). Together with the Tortonian, the Messinian represents the two-fold subdivision of the Upper Miocene Subseries in the Global Standard Chronostratigraphic scale. Controversies concerning the status of the Messinian as global chronostratigraphic unit and the placement of the Miocene/Pliocene boundary have now formally been settled with the official acceptance by the International Commission on Stratigraphy (ICS) and the ratification by the Executive Committee of the International Union of Geological Sciences (IUGS) of both the Zanclean (Lower Pliocene) and Messinian GSSPs.

A brief description of the stratotype-section, of the boundary itself and of the various stratigraphic tools available for global correlation of the Messinian GSSP is presented. Additional information is found in the original proposal (Hilgen et al., 1998) voted by the Subcommission on Neogene Stratigraphy (SNS) and the ICS, and in the literature referred to in the present paper. The integrated stratigraphic data and astronomical tuning of the sedimentary cycles, which underlie the selection of Oued Akrech as stratotype-section, are reported in detail elsewhere (Hilgen et al., 2000).

The original proposal (Hilgen et al., 1998) was forwarded to all SNS voting members in 1998 for postal ballot and almost unanimously accepted. Following the results of the postal ballot, a formal recommendation of SNS was submitted to the Secretary General of the ICS in March 1999. Official acceptance by the ICS and ratification by the IUGS Executive Committee were obtained in July 1999 and January 2000, respectively.

\section{Background and motivation}

Time is ripe to proceed with the definition of the GSSPs of Miocene Stages now that the GSSPs of all Pliocene Stages have been formally defined (Castradori et al., 1998; Rio et al., 1998; Van Couvering et al., 1998, 2000). Much progress has been made during the last years in establishing astronomically dated integrated stratigraphic frameworks for the Upper Miocene, both in the Mediterranean as well as in the open ocean. The Messinian GSSP is the logical first goal also because the long-lasting debate about its chronostratigraphic position and age has been settled (Vai et al., 1993; Krijgsman et al., 1994; Hilgen et al., 1995). The proven unsuitability of both the Messinian neostratotype section at Pasquasia/Capodarso as well as the Falconara section necessitated the search for an alternative boundary stratotype section. Of all candidate sections, Oued Akrech located on the Atlantic side of Morocco is the only section that provided a good to excellent magnetostratigraphy, calcareous plankton biostratigraphy and cyclostratigraphy in the critical interval across the Tortonian/Messinian boundary. An important additional argument for selecting Oued Akrech is to emphasize that the Messinian is a global chronostratigraphic unit and not a Mediterranean Stage of regional significance only, as has been argued for instance by Benson and Rakic-El Bied (1996). But before presenting the integrated stratigraphic data of Oued Akrech, we will start with a condensed review of the history of the Messinian stage concept.

\section{The Messinian Stage: A brief historical review}

\section{Original definition of the Messinian (Mayer-Eymar, 1867)}

The Messinian Stage named after the town of Messina on Sicily (Italy) was introduced by Mayer-Eymar in 1867, and more precisely defined in 1868 to fill up the gap between the Tortonian and the Astian s.l. According to Mayer-Eymar, the latter was equivalent to the entire Pliocene and included the Tabianian, Piacenzian and Astian s.s. Apparently, Mayer erected the Messinian without a (detailed) knowledge of the local stratigraphy of Sicily in order to compete with the Zanclean (= latin name of Messina) Stage introduced by 
Sequenza one year later (Sequenza, 1868). The lack of knowledge of the local stratigraphy becomes evident in Mayer (1868) where he subdivided the Messinian-clearly indicated as post-Tortonian and pre-Astian (s.1.) —of southern Italy more precisely in three units. His listing includes the gypsum of the Gessoso-Solfifera Formation and possibly the diatomites of the underlying Tripoli Formation but contains several pertinent errors (Selli, 1960; Cita, 1975) as well, e.g. the Trubi marls which are now regarded to be of Pliocene (Zanclean) age. His list of stratigraphic units from the Messinian of northern Italy, however, is more precise (Selli, 1960). And in 1878, MayerEymar states explicitly that the middle Messinian is represented by gypsum and associated limestones throughout the Apennines. In the lower Messinian, he includes "gelbliche bis schwärzliche Schiefertone" which may represent the equivalent of the Tripoli diatomite Formation of Sicily. The upper Messinian contains continental deposits, which indicate a regressive phase prior to the (basal) Pliocene transgression.

\section{Messinian neostratotype section of Pasquasia- Capodarso (Selli, 1960)}

The Messinian was adopted as the standard geochronological unit for the interval between the Tortonian and Pliocene during the meeting of the Committee of the Mediterranean Neogene held in Vienna in 1959. Selli (1960) eliminated the existing inconsistencies in the original definition of Mayer-Eymar and defined the Messinian as the "intervallo di tempo compreso fra il Tortoniano (strati di Tortona) e il Pliocene (strati di Tabiano), caratterizzato in tutto il Mediterraneo ... da una crisi di salinità e in Italia essenzialmente da un ambiente iperalino e da sedimenti evaporitici". He proposed the Pasquasia-Capodarso section located on central Sicily as the Messinian neostratotype and argued that the Tortonian/Messinian boundary be placed $25 \mathrm{~m}$ below the local base of the Tripoli diatomite Formation, at the level that coincides with the first marked environmental change which he interpreted as the actual beginning of the salinity crisis. His paleoenvironmental criterion made it difficult, however, to export the boundary, in particular to the extra-Mediterranean realm.

\section{The proposed boundary stratotype of Falconara (Colalongo et al., 1979)}

Calcareous plankton biostratigraphy was subsequently used to define the lower boundary of the Messinian more precisely (D'Onofrio et al., 1975; Mazzei et al., 1979), thus facilitating its recognition on a global scale. The First Occurrence (FO) of the planktonic foraminifer Globorotalia conomiozea (sensu Colalongo et al., 1979) — and the Amaurolithus delicatus FO from a calcareous nannoplankton point of view-appeared to best approximate the beginning of the Messinian salinity crisis sensu Selli (1960). Colalongo et al. (1979) subsequently proposed to emend the Tortonian and Messinian Stages and define the T/M boundary at the G. conomiozea FO level, $6 \mathrm{~m}$ below the base of the Tripoli diatomite Formation in the Falconara section because the boundary interval had been covered by a landslide at Pasquasia-Capodarso. Unfortunately, the Falconara section proved unsuitable for establishing a reliable magnetostratigraphy (Langereis and Dekkers, 1992) and is tectonically disturbed, in particular in the interval below the diatomites. In addition, the boundary interval in the western gully complex has recently been covered by a landslide (field observations, 1997). These observations-once more-necessitated the search for an alternative T/M boundary stratotype section, but the $G$. conomiozea FO could be maintained as guiding criterion for selecting the most suitable section and level to define the Messinian GSSP.

\section{The age of the Tortonian/Messinian boundary}

The initial large uncertainties in the age of Neogene stage boundaries had been reduced with the publication of the first K/Ar datings of marine successions in the Mediterranean (e.g., Eberhardt and Ferrara, 1962; Tongiorgi and Tongiorigi, 1964; Choubert et al., 1968). It was expected that application of the geomagnetic polarity time scale which had just become established at that time (e.g., Heirtzler et al., 1968) should even produce more accurate and precise age determinations. But despite these good prospects, the age of the T/M boundary remained a hotly debated issue in Neogene geochronology and chronostratigraphy for decades. Magnetostratigraphic studies of deep-sea sediments yielded age estimates that ranged from 5.6 to $6.5 \mathrm{Ma}$, pending the synchroneity or diachroneity of bio-events and the exact calibration of magnetostratigraphic records to the geomagnetic polarity time scale (Langereis et al., 1984; Berggren et al., 1985; Channell et al., 1990; Kastens, 1992). The age problem culminated with the publication of a much older $\mathrm{K} / \mathrm{Ar}$ age estimate of $7.26 \mathrm{Ma}$ for the T/M boundary in the northern Apennines (Vai et al., 1993).

The problem was solved with the publication of the GPTS of Cande and Kent (1992). This time scale revealed two additional short normal subchrons in the critical interval spanning the boundary. The extra subchrons allowed a straightforward calibration of high-quality magnetostratigraphic records from Upper Miocene sections on Crete, resulting in an age of 6.92 Ma for the T/M boundary (Krijgsman et al., 1994). The correlation of characteristic sedimentary cycle patterns to the astronomical record resulted in an astronomical age of 7.24 Ma (Hilgen et al., 1995), in good agreement with the radiometric age estimates of Vai et al. (1993) and Laurenzi et al. (1997).

\section{Selecting the most suitable section for defining the Messinian GSSP}

Selecting a section suitable for defining the Messinian GSSP was not a difficult task, despite the unsuitability of both the Falconara and Capodarso/Pasquasia sections. At present, numerous sections are available that cover the critical interval in a continuous marine succession (Monte del Casino in northern Italy; Faneromeni, Potamidha and Kastelli on Crete, Greece; Metochia on Gavdos, Greece; Oued Akrech, Morocco). All these sections have been astronomically dated and cyclostratigraphically correlated (Krijgsman et al., 1995; 1997), and fulfil most if not all the requirements recommended by the ICS (Remane et al., 1996). Of these sections, Oued

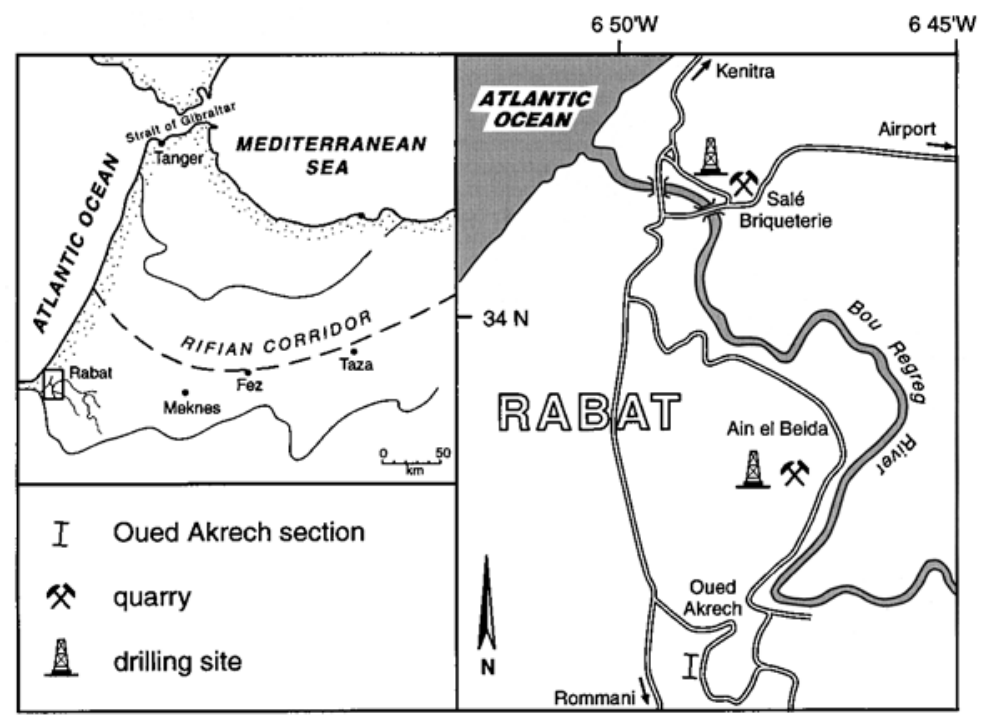

Figure 1 Location map of section Oued Akrech on the Atlantic side of Morocco (NW Africa). 
Akrech located on the Atlantic side of Morocco (Figure 1) stands out al., 1998, 2000). This section contains the lower part of the so-called "Blue Marl" of Atlantic Morocco which ranges in age from the late Tortonian to the early Pliocene.

\section{The Messinian GSSP at Oued Akrech}

The classical Blue Marls of Atlantic Morocco have been the subject of numerous studies, reflecting the progress being made in Neogene biostratigraphy and integrated stratigraphy (e.g., Choubert et al., 1964; Feinberg and Lorenz, 1970; Bossio et al., 1976; Moreau et al., 1985; Wernli, 1977, 1988; Benson et al., 1991, 1995; Hodell et al., 1989, 1994). The entire Oued Akrech road section was studied by Wernli (1977), Cita and Ryan (1978), Benson and co-workers (see Benson and Rakic-El Bied, 1996) and Barbieri (1998), while Sierro et al. (1993) and Hilgen et al. (2000) focussed their studies on the well-exposed lower part only.

\section{The section}

\section{Location}

The Oued Akrech section is located $7 \mathrm{~km}$ SSE of Rabat in a road-cut along a steep bluff next to the Oued Akrech ("oued" = "wadi" = valley; Figure 1), at a latitude of $33^{\circ} 56^{\prime} 13^{\prime \prime}$ and a longitude of $6^{\circ} 48^{\prime} 45^{\prime \prime}$ east of Greenwich. The exposure is along the narrow road that connects the P22 from Rabat (direction Rommani) and the S203, about $3 \mathrm{~km}$ from the junction with the P22 (Figure 2). Oued Akrech is a tributary of the Bou Regreg River that forms a deep valley in southward direction as the river turns to the east (topographic map NI-29-XII-3C coordinates, $370.2-370$ to 371 ).

\section{Stratigraphic succession and geological setting}

The Neogene succession at Oued Akrech starts with an Upper Tortonian shallow marine glauconitic sandstone, locally referred to as "Molasse de Base". This $5 \mathrm{~m}$-thick yellowish coloured sandstone overlies-steeply inclined-Devonian limestones with an angular unconformity and is followed by an indurated phosphatic layer. This layer, which represents a period of a strongly reduced sediment accumulation rate, is succeeded by glauconitic sandy marls and a $2 \mathrm{~m}$-thick deep marine sandy marl with numerous biogenic compoas the most suitable section to define the Messinian GSSP (Hilgen et

nents. The latter contains the solitary coral Flabellum and is locally termed the Coraline Zone.

The part of the Oued Akrech section that is of relevance for the Messinian GSSP starts directly above the Coraline Zone. It consists of deep marine marls known as the Blue Marls after their distinct fresh colour. The weathered colour of these marls as exposed at Oued Akrech, however, is a yellow-beige with reddish colour bands (colour cycles). At the level of the phosphatic layer, the marine depositional environment changed rapidly from sublittoral to upper bathyal (paleodepth 500 to $700 \mathrm{~m}$.) as indicated by the benthic microfauna (Benson and Rakic-El Bied, 1996).

The Blue Marls as exposed in the Oued Akrech section were deposited in the Gharb Basin which represents the westward extension — and opening to the Atlantic — of the Rifian Corridor. The corridor acted as an extensional foredeep during the late Miocene to early Pliocene, separating the active Rif Orogen and nappe complex in the north from the Central Moroccan Meseta to the south (Benson and Rakic-El Bied, 1996), and it formed one of the two AtlanticMediterranean connections during the Neogene. While the marine gateway was closed in the course of the Messinian, deposition of Blue Marls in the Gharb Basin continued well into the Pliocene (e.g., Benson and Rakic-El Bied, 1996).

\section{Magnetobiostratigraphy, isotope stratigraphy and astrochronology}

The Oued Akrech section provided a good to excellent calcareous plankton biostratigraphy, magnetostratigraphy and cyclostratigraphy across the boundary interval (e.g., Hodell et al., 1989; Sierro et al., 1993; Benson and Rakic-El Bied, 1996; Barbieri, 1998; Hilgen et al., 2000) (Figure 3). Detailed magnetobiostratigraphic correlations to time-equivalent and astronomically dated sections in the Mediterranean (Figure 4; Hilgen et al., 2000) revealed that the basic sedimentary cycles are precession-controlled but that precession/ obliquity interference patterns are present as well. The characteristic cycle pattern allows the section to be astronomically tuned by matching the colour cycles (regular alternations of indurated buff coloured marls and softer, more clayey and reddish marls) to correlative patterns in the astronomical target curve (Hilgen et al., 2000; $65^{\circ} \mathrm{N}$ lat summer insolation), thereby providing highly accurate ages for the recorded bio-events and polarity reversals, and, as a consequence, also for the T/M boundary. This calibration is confirmed in detail by the high-resolution calcareous plankton biostratigraphy, thus excluding hiatuses in the astronomically dated part of the section. Sediment accumulation rates can be accurately determined

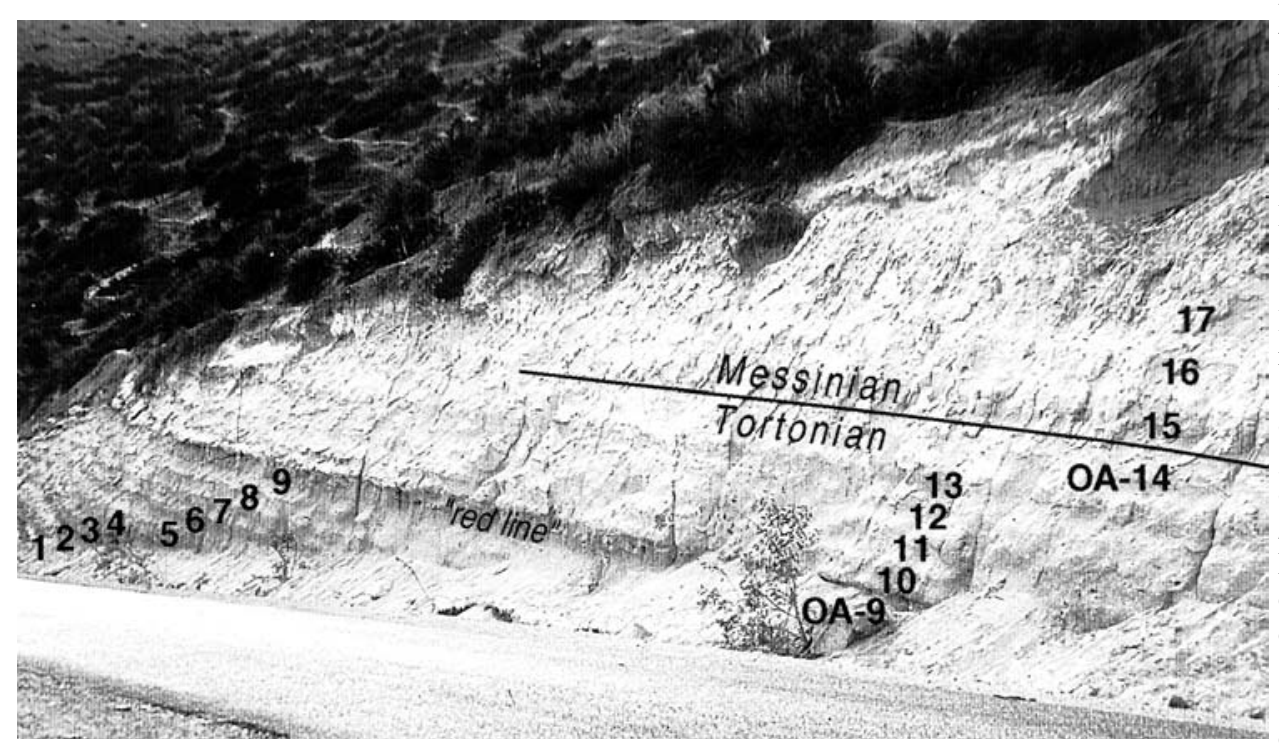
using the astrochronology and vary between 1.5 and $3.5 \mathrm{~cm} / \mathrm{kyr}$ with an increase to $6 \mathrm{~cm} / \mathrm{kyr}$ higher in the section.

Planktonic foraminifera have been studied by Feinberg and Lorenz (1970), Bossio et al. (1976), Wernli (1977), Cita and Ryan (1978), Benson et al. (1991), Sierro et al. (1993), Barbieri (1998) and Hilgen et al. (2000). The quantitative record of the most important marker species (Figure 3) allows the recognition of four distinct events which-in stratigraphical order-are the last common ocurrence (LCO) of Globorotalia menardii 4 of Tjalsma (1971) (= PFEvent 1 of Sierro et al., 1993), the first common ocurrence (FCO) of dextrally coiled G. menardii 5 of Tjalsma (1971) (= PF-Event 2 of Sierro, 1985; Sierro et al., 1993), a prominent sinistral to dextral coiling shift of the Globorotalia scitula group (= PF-Event A of Sierro et al., 1993) and the first regular occurrence (FRO) of the Globorotalia miotumida
Figure 2 Photograph of section Oued Akrech, showing sedimentary cycles $O A$ 1-7 and the position of the Tortonian-Messinian boundary at the base of a reddish bed of cycle OA-15.. 

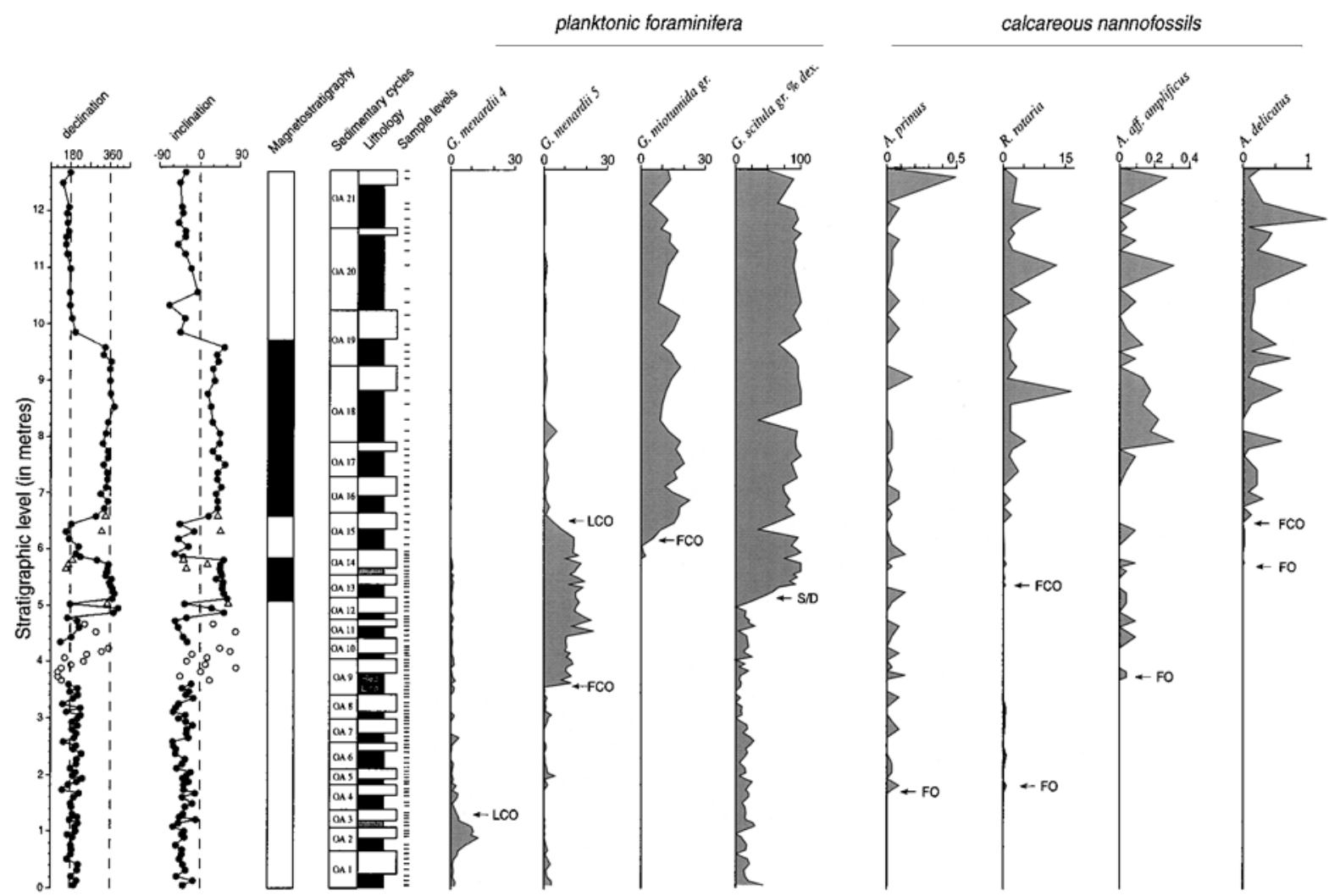

Figure 3 Integrated magnetostratigraphy, calcareous plankton biostratigraphy and cyclostratigraphy of section Oued Akrech.

group (= PF-Event 3 of Sierro et al., 1993 and Globorotalia conomiozea group FRO of Krijgsman et al., 1995). The GSSP falls within (sub)tropical Zone M13b (Globigerinoides extremus/ Globorotalia plesiotumida-Globorotalia lenguaensis Interval Subzone) of Berggren et al. (1995) and the Globorotalia suturae Subzone of Iaccarino (1985), and coincides with the transitional Mt9Mt10 zonal boundary (Globorotalia conomiozeal Globorotalia mediterranea-Globorotalia sphericomiozea Interval Subzone) of Berggren et al. (1995).

Calcareous nannofossils have been studied by Benson and Rakic El-Bied (1996) and Hilgen et al. (2000). Quantitative data reveal the following main events in stratigraphic order: Amaurolithus primus $\mathrm{FO}$, Reticulofenestra rotaria FO, Amaurolithus aff. amplificus FO, $R$. rotaria FCO, Amaurolithus delicatus FO and A. delicatus FCO. The GSSP falls within Zone NN11b of Martini (1971) and Zone CN9b of and Okada and Bukry (1980).

Magnetostratigraphic studies were carried out by Benson and co-workers (Benson and Rakic-El Bied, 1996; see also Hodell et al., 1989) and Hilgen et al. (2000). The more recent magnetostratigraphy is of a very good quality across the boundary (Figure 3 ) and its calibration to the GPTS is straightforward through the integrated stratigraphic correlations to well-calibrated Mediterranean sections (Figure 4). The recorded two normal polarity intervals and intervening reversed interval correspond-from bottom to top-to C3Br.1n, $\mathrm{C} 3 \mathrm{Br}$.1r and $\mathrm{C} 3 \mathrm{Bn}$.

A relatively low resolution benthic stable isotope record has been established for Oued Akrech (Hodell et al., 1989) in which the global Chron 6 Carbon shift can be recognized. This carbon shift can more easily be recognized in the higher resolution isotope record from the Sale drill core (Hodell et al., 1994). In addition, the $\delta^{18} \mathrm{C}$ record from Salé reveals a first step to heavier $\delta^{18} \mathrm{C}$ values around the T/M boundary which coincides closely with the appearance of upper psychrospheric ostracodes (Hodell et al., 1994).

\section{The boundary ("golden spike")}

\section{Definition and age}

The GSSP of the base of the Messinian Stage is now formally defined at the base of reddish layer no.15 in section Oued Akrech (Figure 2). This point coincides closely with the FRO of the planktonic foraminiferal Globorotalia miotumida group and the Amaurolithus delicatus $\mathrm{FO}$, and falls within the interval of reversed polarity that corresponds to $\mathrm{C} 3 \mathrm{Br}$.1r. The base of the reddish layer has been assigned an astronomical age of 7.251 Ma. (Figures 3 and 4).

\section{Correlation tools}

Global correlations are assured by the calibration of the Oued Akrech magnetostratigraphy to the geomagnetic polarity time scale, locating the GSSP in the middle of C3Br.1r. The characteristic polarity pattern allows identification of the boundary in continental settings lacking a direct biostratigraphic control. In the marine realm, the calcareous nannofossil genus Amaurolithus provides a series of extremely useful events to delimit the boundary on a global scale. The A. primus and A. delicatus FOs predate the boundary while the A. amplificus s.s. FO postdates the boundary (Raffi et al., 1995; Backman and Raffi, 1997). The Reticulofenestra rotaria FCO is another useful nannoplankton event that predates the boundary (Negri et al., 1999). The turnover of dominantly dextrally coiled assemblages of $G$. menardii by dominantly sinistrally coiled assemblages of the G. miotumida group can be used to recognise the boundary in the Mediterranean and the adjacent North Atlantic (Sierro, 1985; Sierro et al., 1993).

Stable isotopes yet provide another correlation tool. The Late Miocene Global Carbon isotope shift (in $\delta^{13} \mathrm{C}$ carbonate) straddles the boundary in the open ocean and adjacent basins such as the Mediterranean. It has been identified in Oued Akrech (Hodell et al., 1989) and the Salé drill core (Hodell et al., 1994). In the continental realm, a significant shift in opposite direction is found in terrestrial 


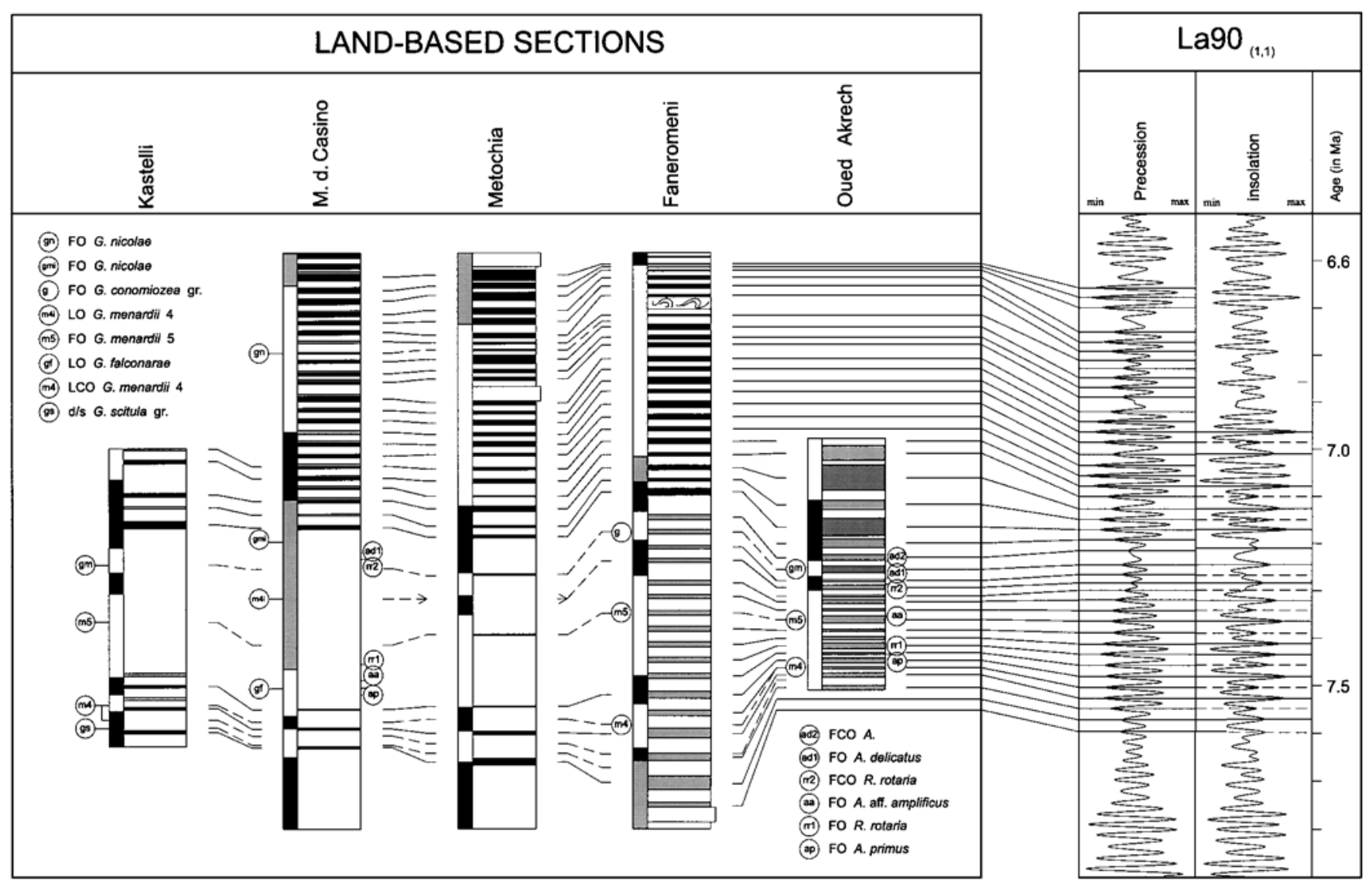

Figure 4 Astronomical tuning of sedimentary cycles OA 1-21 in section Oued Akrech and integrated stratigraphic correlations to timeequivalent and astronomically dated sections in the Mediterranean.

$\delta^{13} \mathrm{C}$. Despite being diachronous on a global scale, the shift approximates the Tortonian/Messinian boundary better than the MiocenePliocene boundary as suggested by Cerling et al. (1997). The acceleration in the worldwide expansion of $\mathrm{C} 4$ grasses, which is associated with the terrestrial $\delta^{13} \mathrm{C}$ shift around the Tortonian/Messinian boundary, resulted in more open habitats on most continents. Although there is no evidence for mammal turnovers exactly at the boundary, major diversity drops and/or shifts from browsing to grazing habits occurred in mammal communities in Asia, Africa and North America between 8 and 6.5 Ma (Alroy, 1992; Morgan et al., 1994).

\section{Conclusion}

The formal definition of the base of the Messinian represents an important next step towards the completion of the Global Standard Chronostratigraphic Scale for the Neogene which is directly linked to high-resolution astronomically dated integrated stratigraphic frameworks.

\section{References}

Alroy, J., 1992, Conjunction among taxonomic distributions and the Miocene mammalian biochronology of the Great Plains: Paleobiology, v. 18, pp. 326-343.

Backman, J. and Raffi, I., 1997, Calibration of Miocene nannofossil events to orbitally-tuned cyclostratigraphies from Ceara Rise: Proc. ODP., Sci. Res., v. 154, pp. 83-99.
Barbieri, R., 1998, Foraminiferal paleoecology at the Tortonian-Messinian boundary, Atlantic coast of northwestern Morocco: J. Foram. Res., v. 28, pp. 102-123.

Benson, R.H., Rakic-El Bied, K., and Bonaduce, G., 1991, An important current reversal (influx) in the Rifian Corridor (Morocco) at the TortonianMessinian boundary: The end of Tethys Ocean: Paleoceanography, v. 6, pp. 164-192.

Benson, R.H., Hayek, L.-A., Hodell, D.A., and Rakic-El Bied, K., 1995 , Extending the climatic precession curve back into the late Miocene by signature template comparison: Paleoceanography, v. 10, pp. 5-20.

Benson, R.H. and Rakic-El Bied, K., 1996, The Bou Regreg section, Morocco: Proposed Global Boundary Stratotype Section and Point of the Pliocene: Notes et Mém. Serv. géol. Maroc., v. 383, pp. 51-150.

Berggren, W.A., Kent, D.V., and van Couvering, J.A., 1985, Neogene geochronology and chronostratigraphy,. in Snelling, N.J., ed., The chronology of the geological record: Geol. Soc. London Mem. v. 10, pp. 211250.

Berggren, W.A., Kent, D.V., Swisher C.C., and Aubry, M.-P. 1995, A revised Cenozoic geochronology and chronostratigraphy,. in Geochronology, Time Scales and Global Stratigraphic Correlatio, SEPM Spec. Publ., v. 54, pp. 129-212.

Bossio, A., Rakic-El Bied, K., Gianelli, L., Mazzei, R., Russo A., and Salvatorini, G., 1976, Correlation de quelques sections stratigraphiques du bassin Méditerranéen sur la base des Foraminiferes planktoniques, nannoplankton calcaire et ostracodes: Atti Soc. Tosc. Sc. Nat. Mem., v. 83, pp. $121-137$

Cande, S.C. and Kent, D.V., 1992, A new geomagnetic polarity time scale for the late Cretaceous and Cenozoic: J. Geophys. Res., v. 97, pp.13.91713.951.

Castradori, D., Rio, D., Hilgen, F.J., and Lourens, L.J., 1998, The Global Standard Stratotype-section and Point (GSSP) of the Piacenzian Stage (Middle Pliocene): Episodes, v. 21, pp. 88-93.

Cerling, T.E., Harris, J.M., MacFadden, B.J., Leakey, M.G., Quade, J., Eisenmann, V., and Ehleringer, J.R , 1997, Global vegetation changes through the Miocene/Pliocene boundary: Nature, v. 389, pp. 153-158. 
Channell, J.E.T., Torii, M., and Hawthorne, T., 1990, Magnetostratigraphy of sediments recovered at Sites 650, 651, 652 and 654 (Leg 107, Tyrrhenian Sea): Proc. ODP Sci. Results, v. 107, pp. 335-346.

Choubert, G., Hottinger, L., Marcais, J., and Suter, G., 1964, Stratigraphie et micropaléontologie du Néogène au Maroc septentrional: Inst. "Lucas Mallada", C.S.I.C. (Espana), Curs. Y Conf.,v. 9, pp. 229-257.

Choubert, G., Charlot, R., Faure-Muret, A., Hottinger, L., Marcais, J, Tisserant, D., and Vidal, P., 1968, Note préliminaire sur le volcanisme messinien-(pontien) au Maroc: C. R. Acad. Sci. Paris, v. 266, pp. 197199.

Cita, M.B., 1975. The Miocene/Pliocene boundary: History and definition, in T. Saito, and L. Burckle, eds., Late Neogene Epoch Boundaries: Micropaleont., Spec. Publ., v. 1, pp. 1-30.

Cita, M.B. and Ryan, W.B.F., 1978, The Bou Regreg section of the Atlantic Coast of Morocco. Evidence, timing and significance of a late Miocene regressive phase: Riv. Ital. Paléont., 84, 1051-1082.

Colalongo, M.L., di Grande, A., D'Onofrio, S., Giannelli, L., Iaccarino, S. Mazzei, R., Poppi Brigatti, M.F., Romeo, M., Rossi, A., and Salvatorini, G., 1979a, A proposal for the Tortonian/Messinian boundary: Ann. Géol. Pays Hellén., Tome hors série, v. 1, pp. 285-294.

D'Onofrio, S., Giannelli, L., Iaccarino, S., Morlotti, E., Romeo, M.,Salvatorini, G., Sampò, M., and Sprovieri, R., 1975, Planktonic foraminifera of the Upper Miocene from some Italian sections and the problem of the lower boundary of the Messinian: Boll. Soc. Paleont. It., v. 14, pp. $177-$ 196.

Eberhardt, P. and Ferrara, G., 1962, Confirmation of the absolute age of the granodiorite outcrop in Elba Island with potassium-argon measurements: Nature, v. 196, pp. 665-666.

Feinberg, H. and Lorenz, H.G. 1970, Nouvelles données stratigraphicques sur le Miocene superieur et le Pliocene du Maroc Nord Occidental: Notes Serv. Geol. Maroc, v. 30, pp. 21-26.

Heirtzler, J.R., Dickson, G.O., Herron, E.M., Pitman III, W.C., and LePichon, X., 1968, Marine magnetic anomalies, geomagnetic field reversals, and motion of the ocean floor and continents: J. Geophys. Res., 73, 2119 2136.

Hilgen, F.J., Krijgsman, W., Langereis, C.G., Lourens, L.J., Santarelli A., and Zachariasse, W.J., 1995, Extending the astronomical (polarity) time scale into the Miocene: Earth Planet. Sci. Lett., v. 136, pp. 495-510.

Hilgen, F.J., Krijgsman, W., Langereis, C.G., Lourens, L.J., Zachariasse, W.J., Iaccarino, S., Villa, G., Benson, R.H., and Dahmani, M., 1998, The Global Boundary Stratotype Section and Point (GSSP) of the Messinian Stage (Uppermost Miocene): A Proposal: Neogene Newsletter, v. 5, pp. $55-77$.

Hilgen, F.J., Bissoli, L., Iaccarino, S., Krijgsman, W., Negri, A., and Villa, G., 2000, Integrated stratigraphy and astrochronology of the Messinian GSSP at Oued Akrech (Atlantic Morocco): subm.

Hodell, D.A., Benson, R.H., Kennett, J.P., Boersma, A., and Rakic-El Bied, K., 1989, Stable isotope stratigraphy of latest Miocene sequences in northwest Morocco: The Bou Regreg section: Paleoceanography, v. 4, pp. 467-482.

Hodell, D.A., Benson, R.H., Kent, D.V., Boersma, A., and Rakic-El Bied, K., 1994, Magnetostratigraphic, biostratigraphic, and stable isotope stratigraphy of an Upper Miocene drill core from the Salé Briqueterie (northwestern Morocco): A high-resolution chronology for the Messinian stage: Paleoceanography, v. 9, pp. 835-855.

Iaccarino, S., 1985, Mediterranean Miocene and Pliocene planktic foraminifera, in Bolli, H.M., Saunders, J.B., and Perch-Nielsen, K. ,eds., Plankton Stratigraphy: Cambridge Univ. Press, pp.283-314.

Kastens, K.A., 1992, Did glacio-eustatic sea level drop trigger the Messinian salinity crisis? New evidence from Ocean Drilling Program Site 654 in the Tyrrhenian Sea: Paleoceanography, v. 7, pp. 333-356.

Krijgsman, W., Hilgen, F.J., Langereis, C.G., and Zachariasse, W.J., 1994 The age of the Tortonian-Messinian boundary: Earth Planet. Sci. Lett., v. 121, pp. 533-547.

Krijgsman, W., Hilgen, F.J., Langereis, C.G., Santarelli, A., and Zachariasse, W.J., 1995, Late Miocene magnetostratigraphy, biostratigraphy and cyclostratigraphy from the Mediterranean: Earth Planet. Sci. Lett., v. 136, pp. 475-494.

Krijgsman, W., Hilgen, F.J., Negri, A., Wijbrans, J., and Zachariasse, W.J., 1997, The Monte del Casino section (northern Apennines, Italy): A potential Tortonian/Messinian boundary stratotype?: Palaeogeogr. Palaeoclimatol. Palaeoecol., v. 133, pp. 27-47.

Langereis, C.G., Zachariasse, W.J. and Zijderveld, J.D.A., 1984, Late Miocene magnetobiostratigraphy of Crete: Mar. Micropaleont., v. 8, pp. 261281 .
Langereis, C.G. and Dekkers, M.J., 1992, Paleomagnetism and rock magnetism of the Tortonian-Messinian boundary stratotype at Falconara, Sicily: Phys. Earth Planet. Inter., 71, 100-111.

Laurenzi, M.A., Tateo, F., Villa, I.M., and Vai, G.B., 1997, New radiometric datings bracketing the Tortonian/Messinian boundary in the Romagna potential stratotype sections (northern Apennines, Italy), in Montanari, A., Odin, G.S., and Coccioni R., eds., Miocene stratigraphy: An integrated approach: Developments in Palaeontology and Stratigraphy, v. 15, pp. 493-530.

Martini, E., 1971, Standard Tertiary and Quaternary calcareous nannoplankton zonation: Proc. II Planktonic Conf., Roma 1970, v. 2, pp. 739-785.

Mazzei, R., Raffi, I., Rio, D., Hamilton, N., and Cita, M.B., 1979, Calibration of Late Neogene calcareous plankton datum planes with the paleomagnetic record of Site 397 and correlation with Moroccan and Mediterranean sections, in U. von Rad, W.B.F. Ryan, et al., Init. Repts: DSDP, v. 47, pp. 375-389.

Mayer-Eymar, K., 1867, Catalogue systématique et descriptif des fossiles des terrains tertiaires qui se trouvent du Musée fédéral de Zürich, Zürich.

Mayer-Eymar, K., 1868. Tableau synchronistique des terrains tertiaires supérieurs, IV ed., Zürich.

Moreau, M.G., Feinberg, H., and Pozzi, J.P., 1985, Magnetobiostratigraphy of a Late Miocene section from the Moroccan Atlantic margin: Earth Planet. Sci Lett., v. 76, pp. 167-175.

Morgan, M.E., Kingston, J.D., and Marino, B.D., 1994, Carbon isotopic evidence for the emergence of $\mathrm{C} 4$ plants in the Neogene from Pakistan and Kenya: Nature, v. 367, pp. 162-165.

Negri, A., Giunta, S., Hilgen, F., Krijgsman W., and Vai, G.B., 1999, Calcareous nannofossil biostratigraphy of the Monte del Casino section (northern Apennines, Italy) and paleoceanographic consideration on the origin of the late Miocene sapropels: Mar. Micropaleont., v. 36, pp. 13 30 .

Okada, H. and Bukry, D., 1980, Supplementary modification and introduction of code numbers to the low-latitude coccolith biostratigraphic zonation (Bukry, 1973; 1975): Mar. Micropaleont., v. 51, pp. 321-325.

Raffi, I., Rio, D., d'Atri, A., Fornaciari, E., and Rocchetti, S., 1995, Quantitative distribution patterns and biomagnetostratigraphy of Middle to Late Miocene calcareous nannofossils from equatorial Indian and Pacific Oceans (Legs 115, 130, and 138), in Pisias, N.G., Mayer, L.A. et al., Proc. ODP, Sci. Results, v. 138, pp. 479-502.

Remane, J., Bassett, M.G., Cowie, J.W., Gohrbrandt, K.H., Richard Lane, H., Michelsen, O., and Naiwen, W., 1996, Revised guidelines for the establishment of global chronostratigraphic standards by the International Commission on Stratigraphy (ICS): Episodes, v. 19, pp. 77-81.

Rio, D., Sprovieri, R., Castradori, D., and di Stefano, E., 1994, The Gelasian Stage (Upper Pliocene): A new unit of the Global Standards Chronostratigraphic Scale: Episodes, v. 21, pp. 82-87.

Selli, R., 1960, Il Messiniano Mayer-Eymar 1867, Proposta di un neostratotipo: Giorn. Geol., v. 28, pp. 1-34.

Sequenza, G., 1868, La formation zancléenne, ou recherches sur une nouvelle formation tertiaire: Soc. Géol. France Bull., ser. 2, v. 25, pp. $465-$ 486.

Sierro, F.J., 1985, The replacement of the "Globorotalia menardii" group by the Goborotalia miotumida group: An aid to recognising the TortonianMessinian boundary in the Mediterranean and adjacent Atlantic: Mar. Micropaleont., v. 9, pp. 525-535.

Sierro, F.J., Flores, J.A., Civis, J., González Delgado, J.A., and Francés, G., 1993, Late Miocene globorotaliid event-stratigraphy and biogeography in the NE-Atlantic and Mediterranean: Mar. Micropaleont., v. 21, pp. 143-168.

Tjalsma, R.C., 1971, Stratigraphy and foraminifera of the Neogene of the Eastern Quadalquivir basin, S. Spain: Utrecht Micropaleont. Bull., v. 5, $109 \mathrm{pp}$.

Tongiorgi, E. and Tongiorgi, M., 1964, Age of the Miocene-Pliocene limit in Italy: Nature, v. 201, pp. 365-367.

Vai, G.B., Villa, I.M. and Colalongo, M.L., 1993, First direct radiometric dating of the Tortonian/Messinian boundary: C. R. Acad. Sci. Paris, v. 316, pp. 1407-1414.

Van Couvering, J., Castradori, D., Cita, M.B., Hilgen, F.J., and Rio, D., 1998, The Global Standard Stratotype-section and Point (GSSP) for the Zanclean Stage and Pliocene Series. A proposal: Neogene Newsletter, v. 5, pp. 22-54.

Wernli, R., 1977, Les Foraminifères planktoniques de la limite mio-pliocéne dans les environs de Rabat (Maroc): Ecl. Geol. Helv., 70, 143-191.

Wernli, R., 1988, Micropaléontologie du Néogène post-nappe du Maroc septentrional et description systématique des Foraminifères planctoniques: Notes et Mém. Serv. géol. Maroc, v. 331, pp. 1-270. 
Frederik J. Hilgen is staff member of the Stratigraphy/Paleontology section at the Faculty of Earth Sciences in Utrecht, the Netherlands. He completed his PhD thesis on the astronomical time scale for the Mediterranean Pliocene-Pleistocene at the Utrecht University in 1991. His current research interest focuses on the extension of the astronomical time scale into the Middle Miocene and the continental realm, and on paleoclimate variability in the annual to (subMilankovitch frequency bands. He is member of working groups on Cyclostratigraphy and the Miocene time scale and will be the new secretary of the Subcommission on Neogene Stratigraphy.

Silvia M. Iaccarino is professor of Micropaleontology at the Department of Earth Science of the University of Parma (Italy). She is a voting member of the Subcommission on Neogene Stratigraphy. Since 1970s she has been working on the Mediterranean Neogene planktonic foraminifer biostratigraphy and chronostratigraphy. Her present research topic concentrates on the high resolution stratigraphy of the middle-late Miocene.

Wout Krijgsman completed his PhD thesis on Miocene magnetostrati-graphy and cyclostratigraphy in the Mediterranean at the Paleo-magnetic laboratory Fort Hoofddijk of the Utrecht University in 1996. He is now a post-doctoral fellow of the Netherlands Research Centre for Integrated Solid Earth Sciences (ISES) and his current research aims at the application of astronomical time scales in tectonostratigraphic analyses of the circum-Mediterranean Miocene.

Willem J. Zachariasse is associate professor in marine micropaleontology and stratigraphy at the University of Utrecht. He is vicepresident of the Subcommission of Neogene Stratigraphy since 1996 and will be the new chairman from September 2000. His present research focuses on (sub)Milankovitch variability in the intensity of the Arabian Sea oxygen minimum zone and monsoonal circulation, and middle to late Miocene planktic foraminiferal biochronology and climate change.
Giuliana Villa is researcher at the University of Parma. She has been working on Cretaceous calcareous nannofossil biostratigraphy of the Northern Apennines, and the Paleogene-Neogene stratigraphy of different areas, in particular of the Mediterranean area. Her current research is focusing on nannofossil paleoecology and biostratigraphy of the Southern Ocean.ences (Utrecht University). His research interests include

Cor Langereis is professor of paleomagnetism and head of the Paleomagnetic Laboratory Fort Hoofddijk from the Faculty of Earth SciEarth Sciences (Utrecht University). His research interests include magnetostratigraphy and polarity time scales, geomagnetic variations and their paleomagnetic recording, and tectonic applications. He is also involved in environmental magnetism, in particular the effect of (paleo)environmental and (paleo)climatic changes on the rock magnetic properties of sediments.

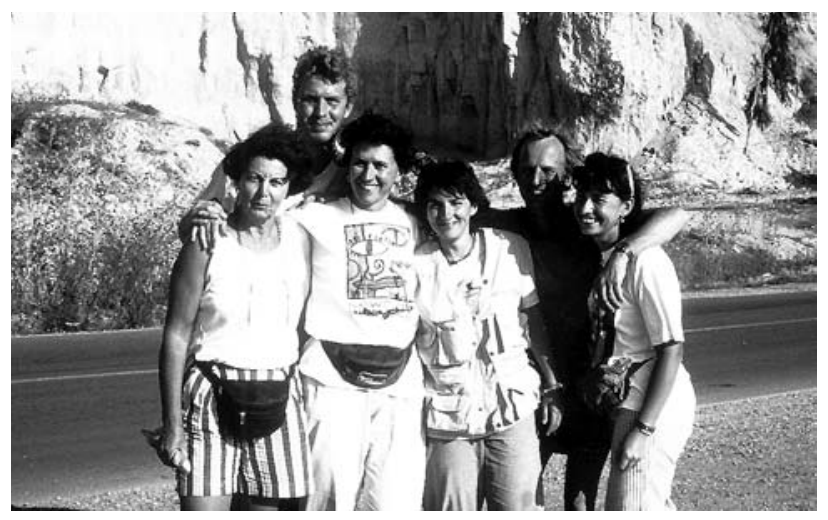

The Utrecht-Parma team after sampling the Oued Akrech and Ain el Beida sections in October 1996. From left to right: Silvia Iaccarino, Wout Krijgsman, GiulianaVilla, Laura Bissoli, Fritz Hilgen, and Sandra Gaboardi.

\section{Hutchison 'Young Scientist' Fund}

William Watt Hutchison, "Hutch" to his many friends around the world, was a Scots-born Canadian geologist who served Canada and the IUGS in myriad dynamic and creative ways. Most notably, he served as the IUGS Secretary General (1976-1980) at a pivotal time in its history, and as IUGS President (1984-1987). The same boundless energy, enthusiasm, skill in communications, and ability to foster teamwork that characterized his work with the IUGS also carried him to preeminent scientific administrative positions in the Canadian Government, where he served as Director General of the Geological Survey of Canada and as Assistant Deputy Minister of Earth Sciences. His distinguished career was terminated in 1987 by his untimely death at the age of 52, following a painful struggle with cancer.

One of Hutch's last wishes was to establish under IUGS auspices a memorial foundation intended to promote the professional growth of deserving, meritorious young scientists from around the world by supporting their participation in important IUGS-sponsored conferences. The first 3 beneficiaries of the Hutchinson "Young Scientist Foundation" attended the 28th International Geological Congress (IGC) in Washington, D.C., in 1989.

The Hutchison "Young Scientist Foundation" is a worthy cause that honors a fine, caring man and a distinguished, public-spirited scientist and administrator. The foundation also celebrates and promotes those things that gave Hutch the most professional satisfaction: geology, international scientific collaboration, and stimulating young minds.

The IUGS welcomes contributions to the Hutchison "Young Scientist Foundation." Please send donations to:

Dr. John A. Reinemund

P.O. Box 890

Leesburg, VA 20178 USA

Fax: +17037774463

Tel: +1 7037771491

Checks in US dollars or Visa/Mastercard (please include account number and expiration date) are preferred in order to avoid the high cost of currency conversions. Residents of the U.S.A. are reminded that charitable gifts of this nature are tax deductible. 